\title{
Dissolved organic carbon fluxes by seagrass meadows and macroalgal beds
}

\author{
Cristina Barrón ${ }^{1 *}$, Eugenia T. Apostolaki² and Carlos M. Duarte ${ }^{3,4,5}$ \\ Griffith School of Environment, Australian Rivers Institute-Coast and Estuaries, and Australian Research Council Centre of Excellence for Coral Reef Studies, \\ Griffith University, Brisbane, QLD, Australia \\ ${ }^{2}$ Hellenic Centre for Marine Research, Institute of Oceanography, Heraklion, Greece \\ ${ }^{3}$ Department of Global Change Research, Instituto Mediterráneo de Estudios Avanzados, Consejo Superior de Investigaciones Científicas-Universitat de les Illes \\ Balears, Esporles, Spain \\ ${ }^{4}$ Faculty of Marine Sciences, King Abdulaziz University, Jeddah, Saudi Arabia \\ ${ }^{5}$ School of Plant Biology, The UWA Oceans Institute, The University of Western Australia, Crawley, WA, Australia
}

\section{Edited by:}

Douglas Patrick Connelly, National

Oceanography Centre, UK

\section{Reviewed by:}

Damien Troy Maher, Southern Cross

University, Australia

Ron Benner, University of South

Carolina, USA

\section{*Correspondence:}

Cristina Barrón, Griffith School of Environment, Australian Rivers Institute-Coast and Estuaries, and Australian Research Council Centre of Excellence for Coral Reef Studies, Nanthan Campus, Griffith University, 170 Kessels Road, Brisbane, Nathan QLD 4111, Australia

e-mail: c.barron@griffith.edu.au
Estimates of dissolved organic carbon (DOC) release by marine macrophyte communities (seagrass meadows and macroalgal beds) based on in situ benthic chambers from published and unpublished are compiled in this study. The effect of temperature and light availability on DOC release by macrophyte communities was examined. Almost $85 \%$ of the seagrass communities and all of macroalgal communities examined acted as net sources of DOC. Net DOC fluxes in seagrass communities increase positively with water temperature. In macroalgal communities net DOC fluxes under light exceeded those under dark condition, however, this trend was weaker in seagrass communities. Shading of a mixed seagrass meadow in The Philippines led to a significant reduction on the net DOC release when shading was maintained for 6 days compared to only 2 days of shading. Net DOC fluxes increased with increasing community respiration, but were independent of primary production or net community production. The estimated global net DOC flux, and hence export, from marine macrophytes is about $0.158 \pm 0.055$ or $0.175 \pm 0.056 \mathrm{Pg}$ $C$ year $^{-1}$ depending on the global extent of seagrass meadows considered.

\section{Keywords: dissolved organic carbon (DOC), seagrass, macroalgae, coastal ecosystems, carbon export}

\section{INTRODUCTION}

Dissolved organic carbon (DOC) represents only $2 \%$ of the carbon pool in the ocean, however, is the largest reservoir of exchangeable organic carbon in the marine carbon pool $(685 \mathrm{Pg}$ C; Hansell and Carlson, 2002). Marine primary producers release part of the carbon fixed photosynthetically as DOC, while the bulk of this organic carbon is consume by bacteria (del Giorgio and Williams, 2005). Bacteria consume preferentially newly synthesized DOC, which is highly labile (Kenworthy and Thayer, 1984), however, a large portion of the bulk DOC pool in the marine ecosystem consists of refractory material which is transported in the ocean (Hansell et al., 2004). Thus, the production and consumption of DOC is a major step in the marine carbon cycle.

Marine macrophytes (i.e., macroalgae and seagrass) form highly productive ecosystems in the coastal ocean (Gattuso et al., 1998; Hemminga and Duarte, 2000; Barrón et al., 2006; Duarte et al., 2010). Marine macrophyte communities are complex assemblages including microbes, metazoans and plants, all of which are involved in dissolved organic matter (DOM) fluxes. These communities can release DOM by different mechanisms, such as release from autotrophic organisms (seagrass, benthic macro- and micro-algae, phytoplankton, and epiphytes), release by leaching, and decomposition of detritus and excretion by organisms all of which can be considered to be of autochthonous origin. DOM can also be produced from release and/or decomposition of organic matter produced elsewhere (i.e., of allochthonous origin), such as DOM derived from decomposition of sestonic material trapped in the sediments (Gacia et al., 2002; Hendriks et al., 2008; Vaquer-Sunyer et al., 2012).

Marine macrophyte communities tend to produce excess organic matter that can be stored in sediments or exported to adjacent ecosystems (Duarte and Cebrián, 1996; Gattuso et al., 1998; Barrón et al., 2003; Duarte et al., 2005; Barrón and Duarte, 2009). Macroalgae and seagrasses store about 0.4 and $16 \%$ of their net primary production in the sediments, respectively (Duarte and Cebrián, 1996), and some of the excess organic matter they produce can be exported to adjacent waters (Duarte et al., 2005; Barrón and Duarte, 2009; Wada and Hama, 2013). The export of organic matter has been reported to account, on average, for 25 and $44 \%$ of the net primary production of macroalgae and seagrass, respectively (Duarte and Cebrián, 1996), although the form, particulate or dissolved, of this release has not been resolved yet. Release of dissolved organic carbon (DOC) by marine macrophytes has been examined mainly in experiments with isolated plants (Brilinsky, 1977; Wetzel and Penhale, 1979; Moriarty et al., 1986; Haas et al., 2010; Kaldy, 2012). DOC release rates of macrophytes isolated under laboratory conditions using ${ }^{14} \mathrm{C}$ addition experiments, concluding that DOC release from macroalgae represented from 1 to $39 \%$ of gross primary production (Khailov and Burlakova, 1969; Brilinsky, 1977; Pregnall, 1983) compared to $<5 \%$ from seagrasses (Brilinsky, 1977; Penhale and 
Smith, 1977; Moriarty et al., 1986). These techniques, however, underestimate the release of DOC from the community because they measure only the carbon recently incorporated by the plant as $\mathrm{DO}^{14} \mathrm{C}$, while they neglect leaching from live and decaying tissues. Haas et al. (2010) reported a net DOC release of $1.3 \pm$ $0.5 \mathrm{mmol} \mathrm{C} \mathrm{m}{ }^{-2} \mathrm{~h}-1$ and $0.2 \pm 0.2 \mathrm{mmol} \mathrm{C} \mathrm{m}^{-2} \mathrm{~h}^{-1}$ using fragments of seagrass and algal specimens, respectively, incubated in beakers under natural daylight conditions. However, extrapolation of DOC release by individual plants to community level underestimates the magnitude of community net release, and hence total DOC export, because it neglects the release of DOC by other components of the community, such as epiphytes, the leaching of DOC from material decomposing in the sediments, and the consumption of DOC by bacteria and possibly metazoans. Indeed, some marine macrophyte communities may possibly act as DOC sinks, consuming more carbon than they produce, a possibility that cannot be ascertained from consideration of DOC release by individual plants alone. Thus, the capacity to export DOC is best assessed through the measurement of net DOC flux by the whole macrophyte community and, especially, using in situ incubations rather than laboratory experiments which do not damage the biological components of the community, ensuring reliable estimates of DOC flux.

Seasonal DOC release by marine macrophyte communities (Ziegler and Benner, 1999; Suzuki et al., 2003; Ziegler et al., 2004; Barrón and Duarte, 2009; Apostolaki et al., 2010a) suggests a dependence of DOC release on temperature and light availability. Metabolic rates were reported to be strongly temperaturedependent in a Mediterranean macroalgae meadow dominated by Caulerpa prolifera, as community respiration and gross primary production were higher when water temperature was around $28^{\circ} \mathrm{C}$ (Vaquer-Sunyer et al., 2012). Most marine macrophyte communities examined displayed net DOC release during light incubations and net uptake during dark (Maher and Eyre, 2010). Indeed, DOC release was on annual scale $12 \%$ higher in the light than in the dark in a Posidonia oceanica meadow (Apostolaki et al., 2010b). Furthermore, bacterial production in the water column of seagrass beds has been reported to vary diurnally (Chin-Leo and Benner, 1991). Additional evidence was provided by Ziegler and Benner (1999), who reported bacterial production and net benthic DOC production to vary between a sunny and a subsequent cloudy day. In addition, Maher and Eyre (2010) reported a tight coupling between DOC fluxes and bacterial biomass. Together, these results suggest a dependence of net DOC release on light availability.

Regrettably, studies examining the DOC flux by marine macrophyte communities in situ are still few (Ziegler and Benner, 1999; Barrón et al., 2003, 2004; Barrón and Duarte, 2009; Apostolaki et al., 2010a,b; Maher and Eyre, 2010). Here we experimentally quantify the net DOC flux by several marine macroalgal and seagrass communities around the world. We examine the effect of ambient water column temperature on net DOC fluxes of seagrass communities. The use of in situ benthic chambers could result in slight differences in the temperature in their interior. However, this minor inconvenient is superseded by the benefit of examining the whole community under near in situ conditions. We also test the effect of light availability on net community
DOC fluxes by comparing them under light and dark in shortterm incubations and by examining the effect of shading on these fluxes in longer-term (days) incubations. We combine our results with our own published estimates as well as those of colleagues to provide an assessment of the global net DOC flux by marine macrophyte communities.

\section{METHODS NET DOC FLUXES FROM MARINE MACROPHYTES}

The net DOC flux of seagrass and macroalgal communities was evaluated in situ using benthic chambers (3-4 replicates) set up by SCUBA divers. The benthic chambers consisted of a PVC cylinder $(18 \mathrm{~cm}$ in diameter) inserted about $7-10 \mathrm{~cm}$ into the sediment and fitted with a polyethylene plastic bag by the divers (Hansen et al., 2000). The polyethylene plastic bags had a sampling port to collect the water samples with $50 \mathrm{ml}$ acid-washed syringes. Most of the DOC fluxes during dark were collected from incubations spanning the entire night period, however, night incubations could not be set up in some locations. In these communities, dark DOC fluxes were estimated using parallel clear benthic chambers and benthic chambers covered with dark plastics bags. These incubations lasted around $2-3 \mathrm{~h}$ in The Philippines, around $4 \mathrm{~h}$ in Ria Formosa, and between 3 and $4 \mathrm{~h}$ in Florida. The volume of each chamber was estimated by injecting $5 \mathrm{ml}$ concentrated phosphate solution $\left(0.25 \mathrm{~mol} \mathrm{l}^{-1}\right)$, and analyzing the water sample for phosphate concentration after mixing at the end of the incubation. The water samples collected were kept frozen until the spectrophotometric determination of the phosphate concentration (Hansen and Koroleff, 1999). The volume of the benthic chambers ranged from 5 to 201 across sites. The volume of each benthic chamber was used to calculate the net DOC fluxes.

An aliquot of the water sample from the benthic chambers was fixed immediately for the determination of dissolved oxygen (DO), whereas the rest was filtered through pre-combusted $\left(450^{\circ} \mathrm{C}\right.$ for $\left.4 \mathrm{~h}\right) \mathrm{GF} / \mathrm{F}$ filters into pre-combusted glass ampoules sealed under heat and analyzed later for DOC. DOC samples collected from March 2001 to May 2001 were kept frozen in acid washed material (glass vials encapsulated with silicone-teflon caps) until analyses. DOC samples collected subsequently were kept acidified with $2 \mathrm{~N} \mathrm{HCl}$ at room temperature in acid-washed sealed ampoules. DOC samples were analyzed in a Shimadzu TOC-5000A (Benner and Strom, 1993). DOC standards provided by Dennis A. Hansell and Wenhao Chen (University of Miami) of 44-45 and $2 \mu \mathrm{mol}$ DOC were used to assess the accuracy of the estimates. Samples for DOC analyses from the experiments conducted in The Philippines were kept frozen and analyzed by high temperature oxidation using an MQ1001 TOC Analyzer (Benner and Strom, 1993). Depending on the experimental location, DO concentration were determined by high-precision Winkler titration with a Mettler DL21 titrator (Carritt and Carpenter, 1966), with a reproducibility of $0.35 \%$, and other samples were measured using a spectrophotometric modification of the Winkler titration method (Pai et al., 1993; Roland et al., 1999).

Fluxes of DOC were based on the rate of change in concentration between initial and final samples. Hourly dark and light DOC rates were converted to daily rates by multiplying the hourly rates by the number of night and light hours during the day. 
Hourly rates of respiration (R) and net community production (NCP) were estimated from the difference in oxygen concentration change in the chambers during the night and the day, respectively. Gross primary production (GPP) was estimated as the sum of the hourly rates of R and NCP. Daily GPP rates were calculated using the photoperiod, daily $\mathrm{R}$ was calculated as hourly $\mathrm{R}$ multiplied by $24 \mathrm{~h}$, and daily rates of NCP were estimated as the difference between daily GPP and R. Metabolic rates in DO units were converted to carbon units assuming photosynthetic and respiratory quotients of 1 (Kirk, 1983).

\section{EFFECT OF TEMPERATURE ON NET DOC FLUXES}

Ambient water column temperature was measured using a data logger (TidBit, Onset ${ }^{\mathrm{TM}}$ ) set up within the $P$. oceanica canopy in Magalluf Bay. Temperature was measured just above the canopy of $P$. oceanica in Sounion by means of a SEABIRD-19 CTD. When water temperature was not measured we searched for temperature values for the site sampled in the literature. For instance literature values were used for measurements in Bolinao, The Philippines (Gacia et al., 2005) and Delta del Ebro, Spain (Llebot et al., 2011).

\section{EFFECT OF SHADING ON NET DOC FLUXES}

The effect of shading on net community DOC release was examined in March 2000 in a mixed seagrass meadow at Silaqui Island, Bolinao (Luzón, The Philippines), and in October 2003 at a Thalassia testudinum meadow in Homossassa, on the Gulf coast of Florida.

Nine separate $2.25 \mathrm{~m}^{2}(1.5 \times 1.5 \mathrm{~m})$ plots were set up in October 2003 in the T. testudinum meadow in Homossassa in the Gulf coast of Florida, experimental details are reported in Calleja et al. (2006). The shading screens (dark gray fiberglass) were established $60 \mathrm{~cm}$ above the seagrass canopy. Shade treatments were $0,1,21,34,48,57,84$, and $86 \%$ light reduction on the eight plots. Benthic chambers were set up in the center of the plot to estimate the DOC fluxes of the T. testudinum community after 5 days of shading. The benthic chambers were deployed for 2.5-4 h during day and night. Net DOC fluxes were measured as described above.

Duplicate $2 \mathrm{~m}^{2}$ plots with shading screens were set up in the mixed seagrass meadow at Silaqui Island (The Philippines), in each of the following treatments: $0,50,65,84,90,95$, and $98 \%$ of reduction of the light incident on the communities. Additional details on the experimental design are reported in Gacia et al. (2005). The DOC fluxes, after 2 and 6 days of shading, were estimated using transparent benthic chambers as described above. An additional series of four benthic chambers with thick black plastic bags fitted to the PVC ring were used to examine net DOC release in communities exposed to short-term (2-4h) darkness.

\section{GLOBAL DOC FLUXES}

Estimates of net DOC fluxes in seagrass derived experimentally here were amended with estimates derived from the literature, resulting in a total of 73 estimates (Table 1), seven of which corresponded to DOC fluxes in macroalgal communities (Table 2). Weighted-mean daily net DOC fluxes by seagrass meadows and macroalgal communities per site were calculate when more than one DOC flux estimate was reported (i.e., mean per DOC fluxes from P. oceanica in Mallorca and Greece). Standard errors of the weighted-average DOC fluxes were calculated using error propagation for each seagrass species per site. These weighted-mean net daily DOC fluxes per site were used to calculate the average net daily DOC fluxes, leading to 28 sites estimates from a total of 66 individual estimates in seagrass communities. A first order approximation of the global net DOC flux from marine macrophyte communities were derive as the product of the weighted average net daily DOC release by marine macrophytes and the global areal extent of seagrass meadows and macroalgal communities.

\section{STATISTICAL ANALYSES}

Least-squares linear regression analysis was used to describe the relationship between the net DOC fluxes and ambient water column temperature in seagrass communities, the net DOC fluxes under light and dark conditions in seagrass and macroalgae communities and between metabolism and net DOC fluxes in macrophyte communities. This analysis was also used to test the relationship between the light reduction and the net DOC fluxes in the shading experiments. We used the Wilcoxon signed rank test to test for tendencies for DOC fluxes in the light and dark to differ consistently. The Wilcoxon ranked sign test was also used to compare the net DOC fluxes after 2 and 6 days of shading in the experiment conducted in The Philippines.

\section{RESULTS}

The maximum net DOC uptake $\left(-53.6 \pm 10.8 \mathrm{mmol} \mathrm{C} \mathrm{m} \mathrm{m}^{-2}\right.$ $\left.\mathrm{d}^{-1}\right)$ and the maximum net release $\left(81.6 \pm 13.9 \mathrm{mmol} \mathrm{C} \mathrm{m}^{-2}\right.$ $\mathrm{d}^{-1}$ ) were both observed in C. nodosa communities (Table 1 , Figure 1A). DOC release ranged an order of magnitude across macroalgal communities from $8.4 \pm 1.6 \mathrm{mmol} \mathrm{C} \mathrm{m} \mathrm{m}^{-2} \mathrm{~d}^{-1}$ in C. prolifera to $71.9 \pm 33.2 \mathrm{mmol} \mathrm{C} \mathrm{m} \mathrm{m}^{-2} \mathrm{~d}^{-1}$ in Halimeda tuna (Table 2, Figure 1B). The net DOC fluxes in seagrass communities were significantly correlated with the water temperature $\left(r^{2}=0.1, p<0.05\right)$, increasing by $1.5 \pm 0.7 \mathrm{mmol} \mathrm{C} \mathrm{m}^{-2} \mathrm{~d}^{-1}$ by each ${ }^{\circ} \mathrm{C}$ temperature increase (Figure 2 ).

Light and dark net DOC flux were significantly correlated in seagrass $\left(r^{2}=0.17, p<0.05\right)$ and macroalgal $\left(r^{2}=0.72\right.$, $p<0.05$ ) communities (Figure 3). Net flux of DOC tended to be higher under light than dark conditions in macroalgal communities (Wilcoxon ranked sign test, $p<0.05$; Figure 3A). However, although 30 out of 46 seagrass communities tended to support higher net DOC fluxes under light than under dark, this tendency was not statistically significant (Wilcoxon ranked sign test, $p>0.05$; Figure 3A). An important fraction (40\%) of the marine macrophyte communities studied had a net DOC flux under light conditions at least two fold higher than that in the dark (Figure 3B). There was no significant correlation between either GPP or NCP and net DOC fluxes for both seagrass and macroalgal communities ( $p>0.05$, Figures 4A,C). However, community $\mathrm{R}$ and net DOC flux were significantly correlated in seagrass communities $\left(r^{2}=0.12, p<0.05\right.$, Figure 4B), but not in macroalgal communities.

Experimentally-shaded T. testudinum communities in Homossassa (Florida) supported net DOC fluxes ranging from 
Table 1 | Net dissolved organic carbon (DOC) fluxes (mean $\pm S E$; rates in $\mathrm{mmol} \mathrm{C}^{-2} \mathrm{~d}^{-1}$ ) in seagrass meadows.

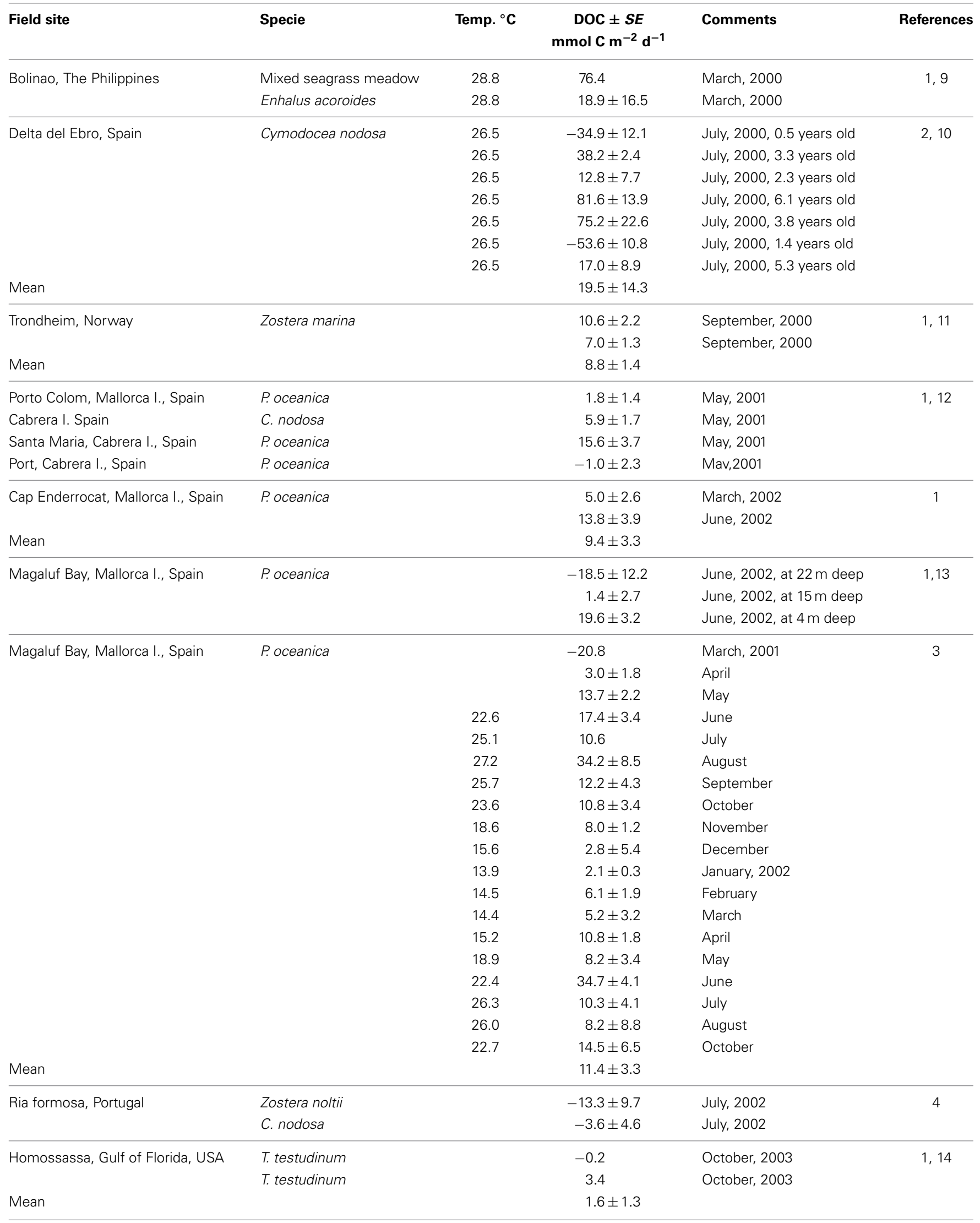


Table 1 | Continued

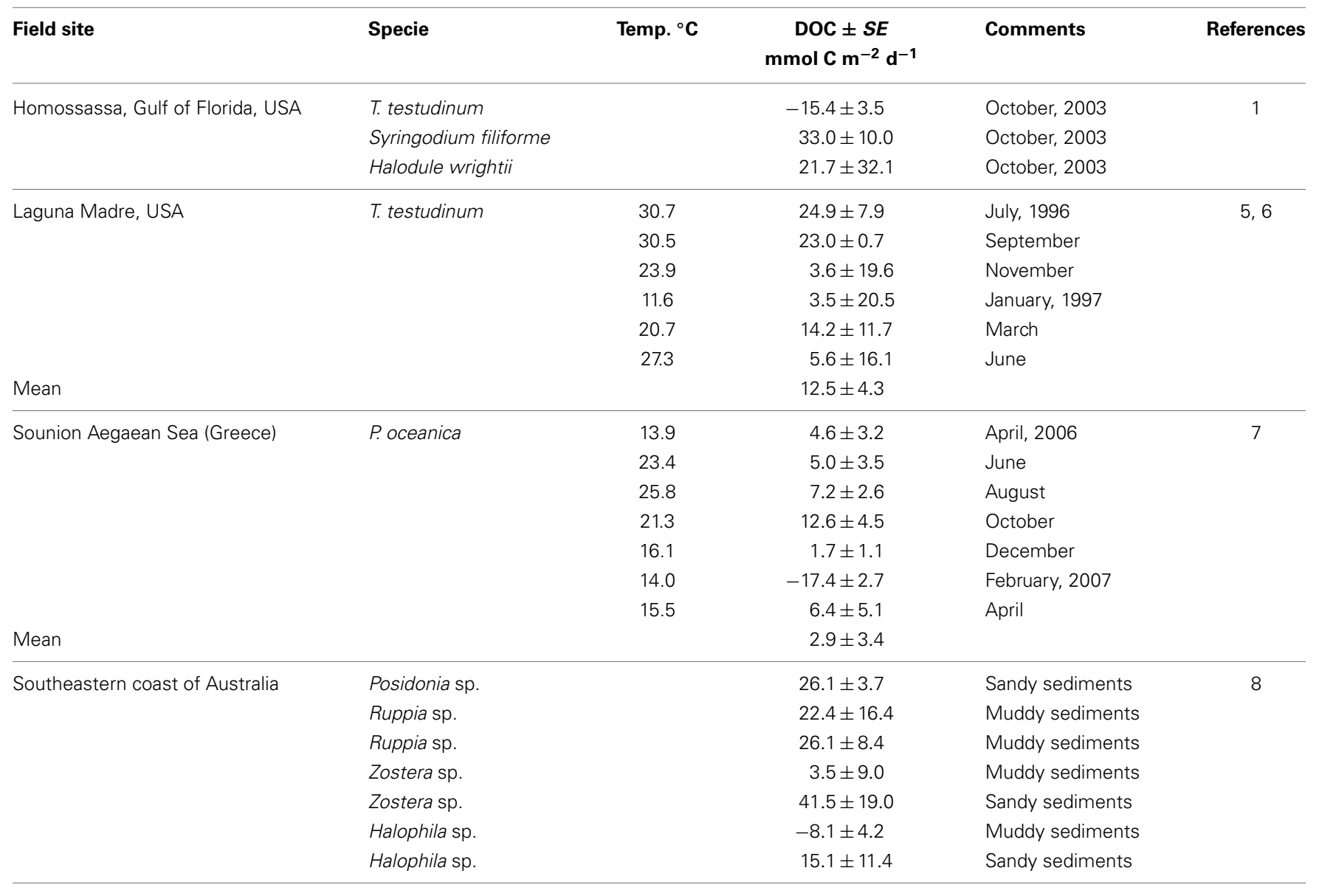

Average

$12.4 \pm 2.9$

Negatives values represent net uptake while positive values represent net release. Weighted mean DOC fluxes per site. Overall average of DOC fluxes are reported at the bottom. References are shown in the note.

Note. 1, This study; 2, Barrón et al., 2004; 3, Barrón and Duarte, 2009; 4, Santos et al., 2004; 5, Ziegler and Benner, 1999; 6, Ziegler et al., 2004; 7, Apostolaki et al., 2010a; 8, Maher and Eyre, 2010. Water column temperature 9, Gacia et al., 2005; 10, Llebot et al., 2011. Metabolism data: 11, Duarte et al., 2002; 12, Holmer et al., 2004; 13, Gazeau et al., 2005; 14, Calleja et al., 2006.

a net uptake of $-10.4 \mathrm{mmol} \mathrm{C} \mathrm{m}^{-2} \mathrm{~d}^{-1}$ to a net DOC release of $31.9 \mathrm{mmol} \mathrm{C} \mathrm{m}^{-2} \mathrm{~d}^{-1}$ (Table 3), independently of the level of shading imposed $\left(r^{2}=0.13, p>0.05\right)$. The mixed seagrass meadow in The Philippines acted as a source of DOC under all irradiances after 2 days of shading, except for a small net DOC uptake of $-25.3 \mathrm{mmol} \mathrm{C} \mathrm{m} \mathrm{m}^{-2} \mathrm{~d}^{-1}$ at $88.2 \%$ of light reduction. However, after 6 days of shading all the communities receiving $>10 \%$ of incident light ( 7 plots in total) reverted to net DOC uptake, and only a net DOC release of $284.9 \mathrm{mmol} \mathrm{C}$ $\mathrm{m}^{-2} \mathrm{~d}^{-1}$ persisted at $98 \%$ shading (Figure 5). Net DOC flux in the experimentally-shaded mixed meadow was independent of the level of shading imposed after 2 days of shading $\left(r^{2}=0.11\right.$, $p>0.05)$ and after 6 days of shading $\left(r^{2}=0.11, p>0.05\right)$. However, the net DOC fluxes in this seagrass meadow were significantly reduced after 6 days of experimental shading (Wilcoxon ranked sign test, $p<0.05$ ) compared to net DOC fluxes after 2 days of shading.
The net DOC flux by seagrass meadows averaged $12.4 \pm$ $2.9 \mathrm{mmol} \mathrm{C} \mathrm{m}^{-2} \mathrm{~d}^{-1}$ (Table 1), with $83 \%$ of the seagrass meadows tested acting as sources of DOC to the surrounding water (Figure 1A). All macroalgal communities studied acted as net sources of DOC (Table 2, Figure 1B), with a higher average $( \pm S E)$ net DOC flux of $23.2 \pm 12.6 \mathrm{mmol} \mathrm{C} \mathrm{m}^{-2} \mathrm{~d}^{-1}$ than that supported by seagrass meadows.

\section{DISCUSSION}

Published measurements of DOC release by marine macrophyte communities were few prior to the present study (Tables 1, 2). Maher and Eyre (2010) reported net DOC release by several seagrass communities studied in the South-eastern coast of Australia ranging from 3.5 to $41.5 \mathrm{mmol} \mathrm{C} \mathrm{m}^{-2} \mathrm{~d}^{-1}$, except for a net DOC uptake of $8.1 \mathrm{mmol} \mathrm{C} \mathrm{m}^{-2} \mathrm{~d}^{-1}$ in Halophila sp. (Table 1). Ziegler and Benner (1999) reported a consistent net DOC release by a T. testudinum community in the Gulf of Mexico, ranging 
Table 2 | Net dissolved organic carbon (DOC) fluxes (mean $\pm S E$; rates in mmol $\mathrm{C} \mathrm{m}^{-2} \mathrm{~d}^{-1}$ ) in macroalgal communities.

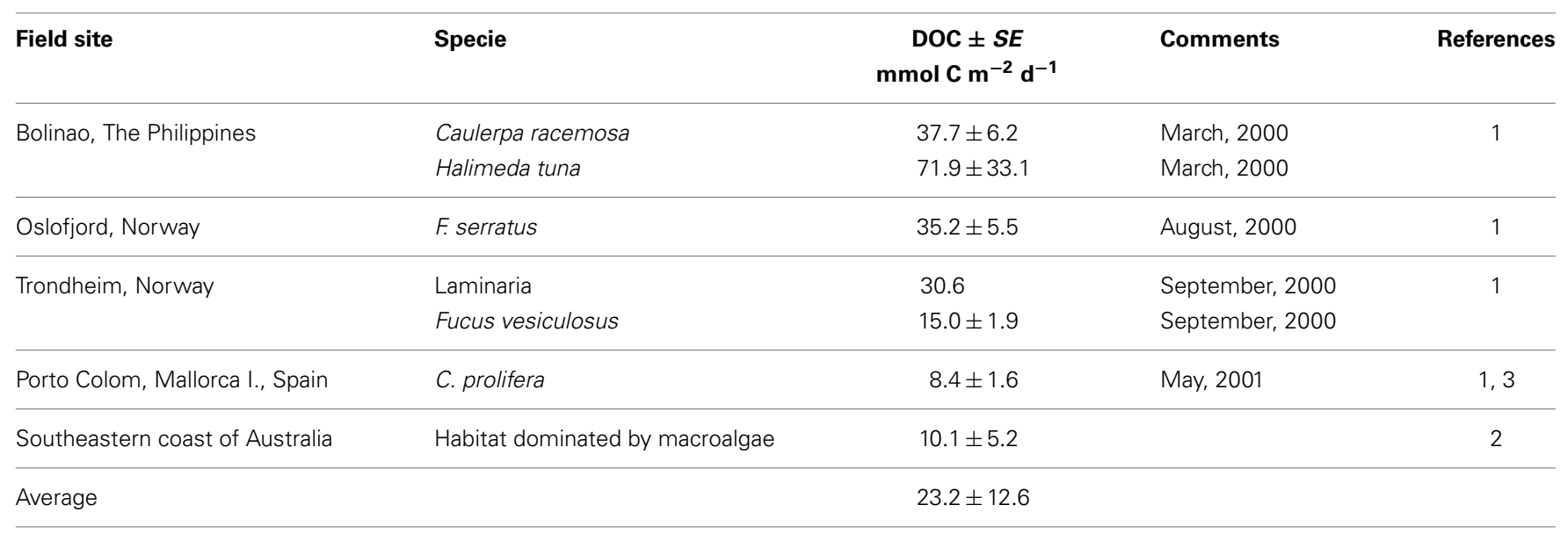

Positive values represent a net release. References are shown in the note.

Note: 1, This study; 2, Maher and Eyre, 2010. Metabolism data: 3, Holmer et al., 2004.

from 3.6 to $24.9 \mathrm{mmol} \mathrm{C} \mathrm{m}^{-2} \mathrm{~d}^{-1}$, which were substantially higher than the estimates of net DOC fluxes in the T. testudinum community studied here (Table 1). Velimirov (1986) reported a net DOC release by a Mediterranean $P$. oceanica community of $40.2 \mathrm{mmol} \mathrm{C} \mathrm{m}^{-2} \mathrm{~d}^{-1}$ (Velimirov, 1986), which must be considered with caution as DOC concentrations in this report varied by almost 10 fold. Most (90\%) of the experiments conducted in $P$. oceanica communities supported a net DOC release, with a maximum DOC release of $34.7 \mathrm{mmol} \mathrm{C} \mathrm{m}^{-2} \mathrm{~d}^{-1}$. Barrón et al. (2004) reported a transition of communities of the seagrass C. nodosa in a Mediterranean Bay from a net sink to net source of DOC along the colonization process. The results presented show that marine macrophyte communities generally act as net sources of DOC to the ecosystem, $85 \%$ of the relative communities studied supported a net DOC release. Rates for individual net DOC fluxes in seagrass communities vary greatly between a net DOC uptake of $53.6 \pm 10.8 \mathrm{mmol} \mathrm{C} \mathrm{m}^{-2} \mathrm{~d}^{-1}$ to a net DOC release of $81.6 \pm 13.9 \mathrm{mmol} \mathrm{C} \mathrm{m}^{-2} \mathrm{~d}^{-1}$. Multiple components of the marine macrophyte communities (including microbes, metazoans, and plants) might be responsible for a net DOC uptake in seagrass communities. For instance, planktonic respiration might be enhanced within the canopy and could lead to a net DOC uptake in seagrass communities. In addition, metazoans can also consume DOC, a possibility well established for sponges, for which DOC uptake may provide around $80 \%$ of their organic carbon demand (Mueller et al., 2014). Furthermore, Vonk et al. (2008) using stable isotopes report that seagrass leaves take up dissolved organic nitrogen, thereby implying the uptake of DOC, but this has uptake by seagrass leaves has never been investigated directly. Likewise, net DOC release maybe supported by multiple components, including the plants themselves, epiphytic community, benthic micro- algae, phytoplankton, plant litter, metazoans, and release from sediment organic carbon. However, the relative contribution of each component to the net DOC uptake has not yet been apportion for seagrass communities, which is, therefore, an open question that requires further attention. Published reports of DOC release by macroalgal communities were few. Net DOC release by a macroalgal-dominated community in the
South-eastern coast of Australia was $10.1 \pm 5.2 \mathrm{mmol} \mathrm{C} \mathrm{m}^{-2} \mathrm{~d}^{-1}$ (Maher and Eyre, 2010). In our study, all the macroalgal communities were net sources of DOC to the ecosystem ranging from $8.4 \pm 1.6$ to $71.9 \pm 33.1 \mathrm{mmol} \mathrm{C} \mathrm{m}^{-2} \mathrm{~d}^{-1}$. Wada and Hama (2013) report that macroalgae contribute up to $20 \%$ of total DOC concentration in Oura Bay in Japan.

Ziegler and Benner (1999) showed that the net DOC fluxes in a T. testudinum community were higher in the light, ranging between a release of $8.4-22.9 \mathrm{mmol} \mathrm{C} \mathrm{m} \mathrm{m}^{-2} \mathrm{~d}^{-1}$, while in the dark DOC fluxes varied from a net uptake of 7.7 to a net release of $8.4 \mathrm{mmol} \mathrm{C} \mathrm{m}^{-2} \mathrm{~d}^{-1}$, and that DOC fluxes under the light being significantly correlated with NCP. Our results also revealed a tendency for marine macrophyte communities to support higher net DOC fluxes under the light than in the dark, a tendency that was particularly strong in macroalgae communities. $P$. oceanica communities had higher net DOC release rates in summer than in winter when water temperature was higher (Barrón and Duarte, 2009), despite the increase in bacterial carbon demand with increased temperature (Kritzberg et al., 2010). The absence of any significant relationship between net DOC fluxes and GPP or NCP across communities suggests a weak coupling between light availability and community photosynthetic activity or net community DOC release. However, there was a significant relationship between community respiration and net DOC fluxes, as reported previously for a $C$. nodosa community (Barrón et al., 2004). Several studies link community respiration and DOC fluxes in marine macrophyte communities. Community respiration in a Mediterranean macroalgal community dominated by $C$. prolifera is driven by the release of DOC (Vaquer-Sunyer et al., 2012). Maie et al. (2006) reported high DOC release during decomposition of the seagrass T. testudinum, with $80 \%$ of the DOC leached over the first week of decomposition. This suggests that the relationship between community respiration rate and net DOC release rate may derive from high DOC release and respiration rates.

Further insight into the relationship between incident irradiance, photosynthetic activity, and net DOC release was derived from the two shading experiments conducted here. Net DOC 

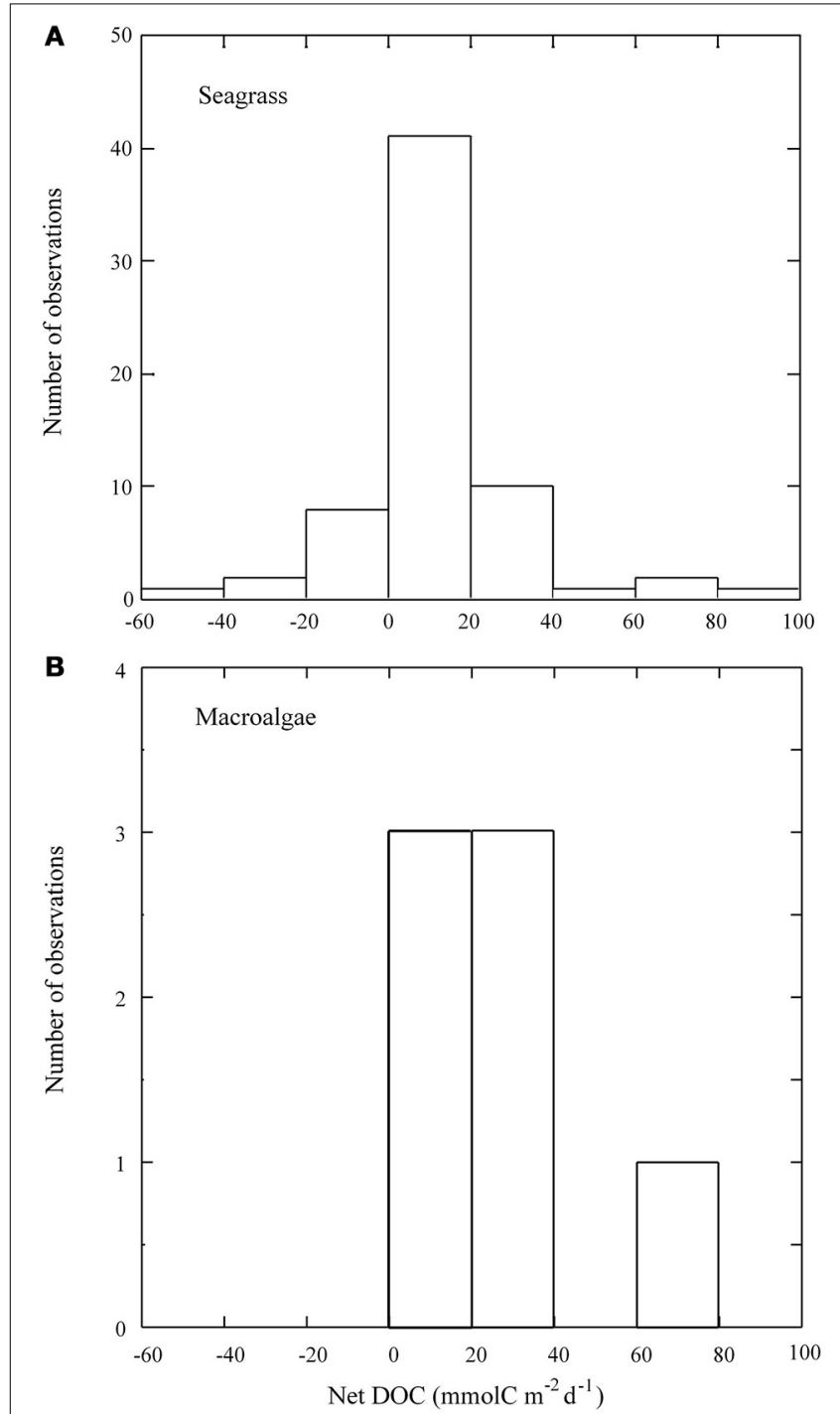

FIGURE 1 | Frequency distribution of the net daily DOC fluxes ( $\mathrm{mmol} C$ $\mathbf{m}^{-2} \mathbf{d}^{-1}$ ) in (A) seagrass and (B) macroalgal communities. Average \pm SE shown. Individual estimates from Tables 1, 2.

fluxes were not affected by shading for 5 days of a $T$. testudinum community, whereas the GPP and NCP, but not respiration rates of this seagrass meadow were significantly reduced (Calleja et al., 2006). Shading of a mixed seagrass meadow in The Philippines did not lead to any significant reduction in net DOC release after 2 days of shading, but it led to a significant reduction of the net DOC release when shading was maintained for 6 days. These results suggest, therefore, that whereas net community DOC release is not supported by fresh photosynthetic activity, the necessary coupling between photosynthetic production and DOC release occurs at time scales of a few days in seagrass meadows. The reduction in net DOC fluxes after 6 days of shading could have been caused by a reduction of the net DOC release from seagrass communities or by an increase in DOC consumption due to mainly bacterial respiration as suggested above.

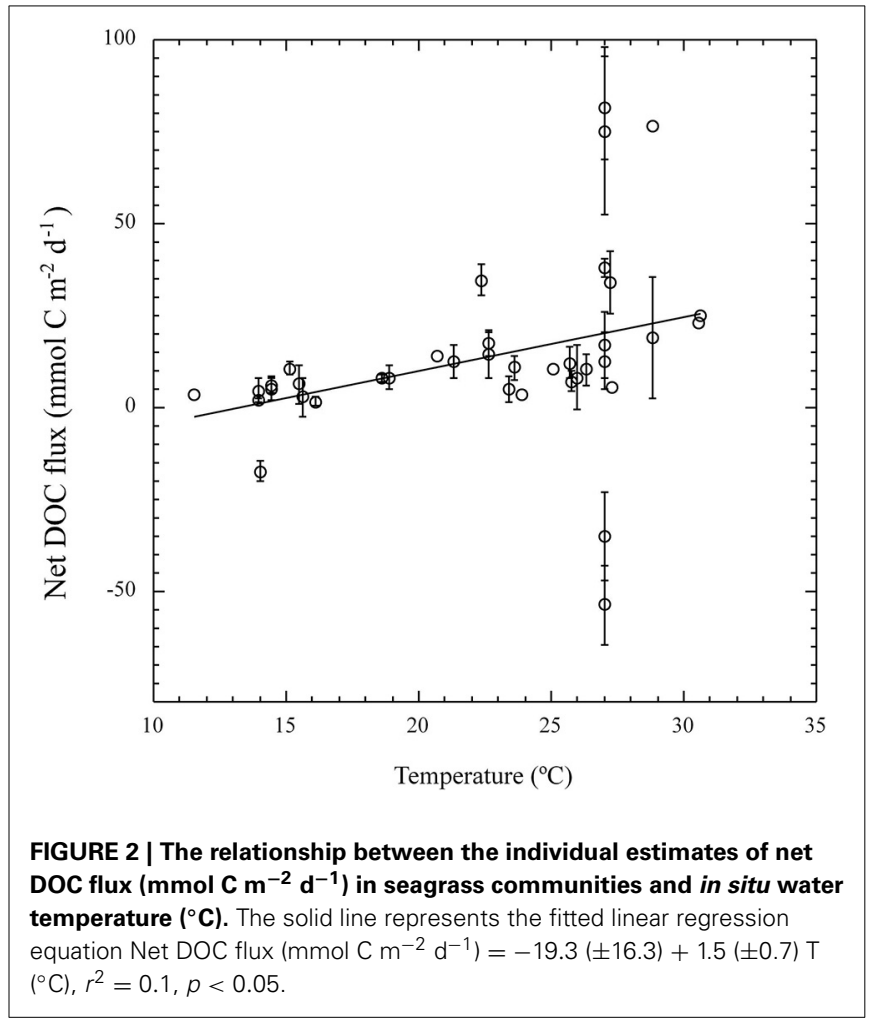

DOC release by a $T$. testudinum community represented about $10 \%$ of the net community production in Laguna Madre (Ziegler and Benner, 1999). The rates of net DOC release by seagrass communities reported here represented on average $38 \%$ of the GPP, but $83 \%$ of their NCP. The net DOC release in macroalgal communities represented on average $27 \%$ of the GPP but more than $300 \%$ of the NCP. Because carbon burial and particulate carbon export by macrophyte beds typically exceed $40 \%$ of NPP (Duarte and Cebrián, 1996), the high net DOC release relative to $\mathrm{NCP}$ of the macrophyte communities studied here is unlikely to be supported by autochthonous photosynthetic production alone (Barrón et al., 2004). Recently, Maher and Eyre (2011) reported that the $\delta^{13} \mathrm{C}$-DOC value from estuarine water column is similar to the seagrass and algal ${ }^{13} \mathrm{C}$ values indicating that the DOC pool was dominated by macrophytederived DOC. However, inputs and subsequent decay of seston in seagrass sediments (e.g., Gacia et al., 2002; Hendriks et al., 2008; Kennedy et al., 2010), may play an important role in supporting the net DOC release of macrophyte communities. Use of stable isotopes to explore the link between macrophyte communities and DOC pools will help to further resolve the sources of DOC fluxes, autochthonous or allochthonous, in these communities.

The total global net DOC flux from marine macrophytes was estimated using the weighted average net DOC release by marine macrophytes derived here of $4521.6 \pm 1073.1 \mathrm{mmol} C$ $\mathrm{m}^{-2}$ year $^{-1}$ and $8457.1 \pm 4602.7 \mathrm{mmol} \mathrm{C} \mathrm{m}^{-2}$ year $^{-1}$ for seagrass meadows and macroalgal communities, respectively, and the area estimated to be covered by macroalgae $(1.4 \times 1012$ $\mathrm{m}^{2}$, Duarte et al., 2005) and seagrass meadows $\left[0.3 \times 1012 \mathrm{~m}^{2}\right.$ 


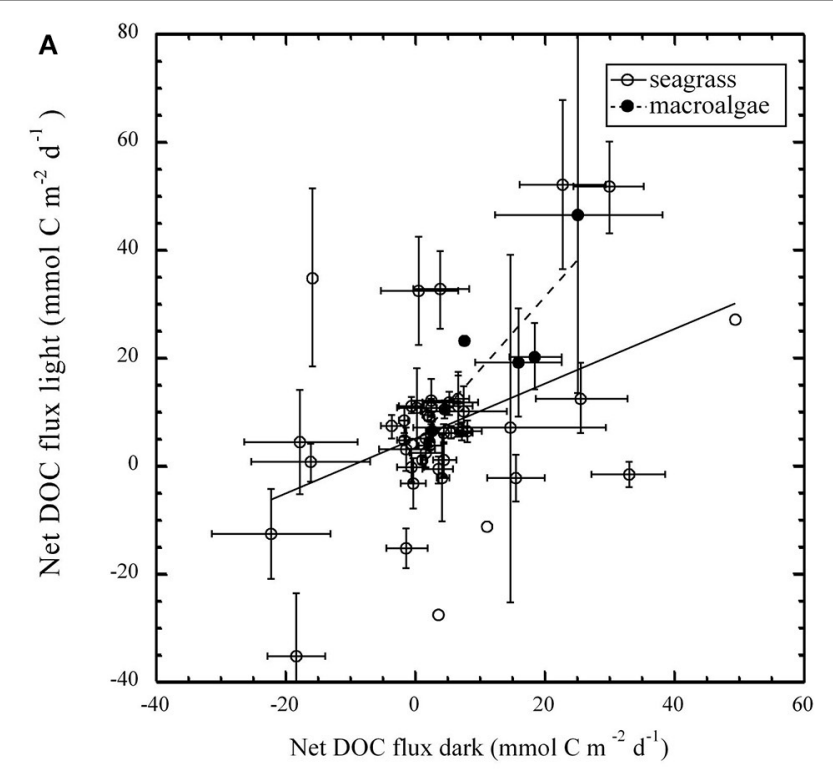

B

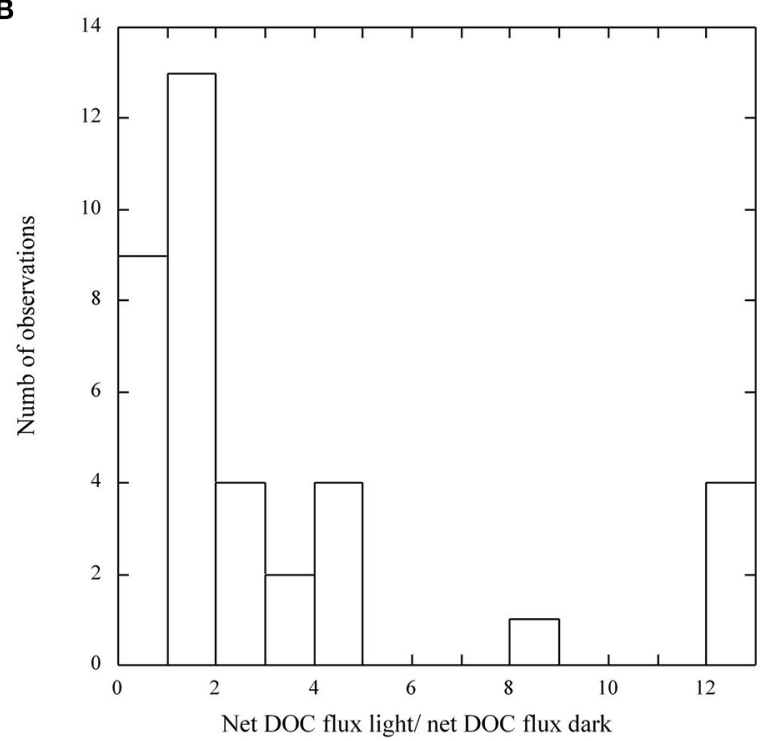

FIGURE 3 | (A) The relationship between the individual estimates of net DOC flux under light and dark conditions in macroalgal and seagrass communities. The solid line represents the linear regression fitted for seagrass communities Net DOC light $\left(\mathrm{mmol} \mathrm{C} \mathrm{m}^{-2} \mathrm{~d}^{-1}\right)=4.7( \pm 2.24)+$ $0.5( \pm 0.2)$ Net DOC dark, $r^{2}=0.17, p<0.01$. The dashed line represents the linear regression fitted for macroalgal communities: Net DOC light $\left(\mathrm{mmol} \mathrm{C} \mathrm{m}{ }^{-2} \mathrm{~d}^{-1}\right)=4.7( \pm 6.1)+1.3( \pm 0.4)$ Net DOC dark, $r^{2}=0.72$, $p<0.05$; Average $\pm S E$ shown. (B) Frequency distribution of the ratio of net DOC fluxes in light and dark when both fluxes had a positive ratio (both net release or net uptake).

(Duarte et al., 2005) to $0.6 \times 1012 \mathrm{~m}^{2}$ (Charpy-Roubaud and Sournia, 1990)]. The estimated global net DOC flux, and hence export, from seagrass meadows ranged from $0.016 \pm 0.004 \mathrm{Pg} C$ year $^{-1}$ to $0.033 \pm 0.008 \mathrm{Pg} \mathrm{C}$ year ${ }^{-1}$ depending on whether the low or high estimates of global seagrass cover is used, respectively. This range encompasses the global net DOC flux of 0.019 Pg C year $^{-1}$ estimated by Maher and Eyre (2010). The global net DOC export from seagrass meadows reported here represents $46 \%$ of
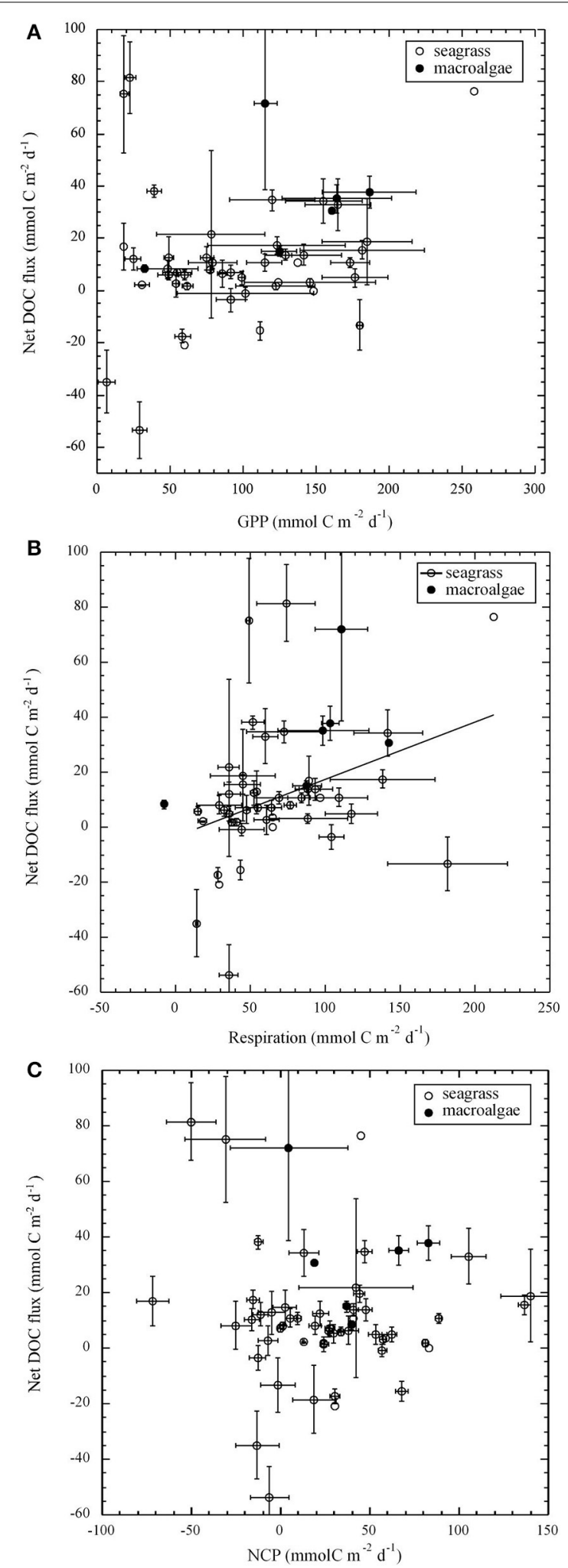

FIGURE 4 | The relationship between gross primary production (A; GPP), respiration (B; R) and net community production (C; NCP) and net DOC flux in seagrass and macroalgal communities using individual estimates from Tables 1, 2. The solid line represents the fitted linear (Continued) 


\section{FIGURE 4 | Continued}

regression equation between respiration and net DOC flux in seagrasses; Net DOC flux (mmol C m-2 $\left.\mathrm{d}^{-1}\right)=-2.5( \pm 6.3)+0.2( \pm 0.1) R, r^{2}=0.12$, $p<0.05$.

Table 3 | Net DOC flux (mmol $\mathrm{Cm}^{-2} \mathrm{~d}^{-1}$ ) in the Thalassia testudinum meadow after 5 days of shading (\% light reduction) in Florida.

\begin{tabular}{lc}
\hline \% Light reduction & $\begin{array}{c}\text { Net DOC fluxes } \\
\mathbf{m m o l ~ C ~} \mathbf{~ m}^{\mathbf{2}} \mathbf{~ d}^{\mathbf{- 1}}\end{array}$ \\
\hline 0 & 3.4 \\
1 & -0.2 \\
21 & -10.4 \\
34 & 31.9 \\
48 & 4.3 \\
57 & -5.0 \\
84 & 20.4 \\
86 & 11.0 \\
\hline
\end{tabular}

Negative values represent net DOC uptake.

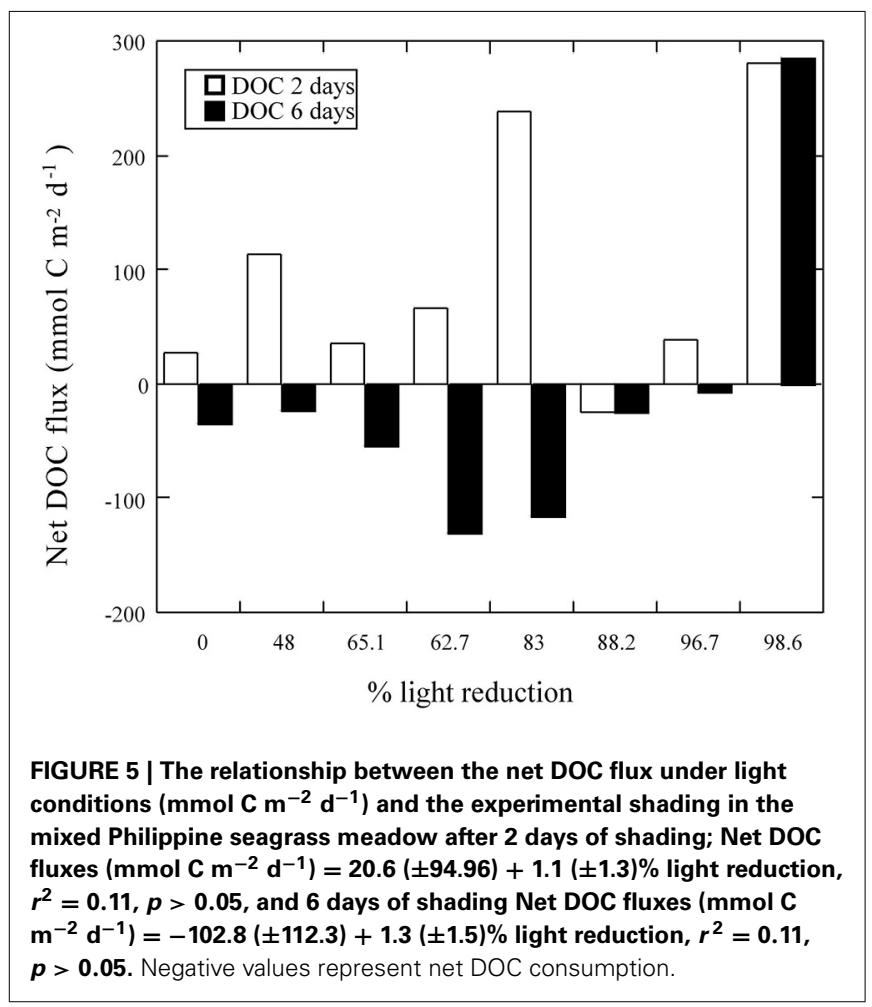

the global NCP of seagrass meadows calculated by Duarte et al. (2010). This high export of dissolved organic carbon in relation to the seagrass NCP could be partly supported by allochthonous carbon inputs, derived from the capacity of seagrass canopies to trap particulate material from the water column (e.g., Hendriks et al., 2008). Indeed, in general, half of the organic carbon in seagrass sediments is of allochthonous origin (Kennedy et al., 2010), some of which could be released as DOC. The estimated global net DOC export from macroalgal beds is $0.14 \pm 0.08$ $\mathrm{Pg} \mathrm{C}$ year $^{-1}$, well above that of seagrass meadows and in the range of other global DOC export estimates from macroalgae beds estimated at $0.061 \mathrm{Pg} \mathrm{C}$ year $^{-1}$ (Maher and Eyre, 2010) and $0.34 \mathrm{Pg} \mathrm{C}_{\text {year }}{ }^{-1}$ (Hughes et al., 2012). Thus, the global net DOC release by marine macrophytes supports a net carbon export of about $0.158 \pm 0.055 \mathrm{Pg} \mathrm{C}_{\text {year }}{ }^{-1}$ to $0.175 \pm 0.056$ $\mathrm{Pg} \mathrm{C}$ year $^{-1}$. We acknowledge that this estimate bears considerable uncertainties. First, the total number of net DOC flux estimates from marine macrophytes available is still limited, particularly in the Southern Hemisphere. For instance, only $11 \%$ of the individual estimates of net DOC fluxes from seagrass communities are from the Southern Hemisphere, specifically from Southeastern coast of Australia. In addition, a second source of uncertainty is that this study represents only the net DOC fluxes from 10 seagrass species addressing that more than 40 of seagrass species have not been studied yet in relation to its net DOC fluxes. This lack of knowledge is even higher as we report just 7 estimates of net DOC fluxes out of the thousands macroalgae species. We acknowledge that the available data are still limited in terms of the total number of communities investigated, their geographic spread and their suitability to represent an annual flux. Hence, further efforts are needed to extend and increase the estimates of net DOC fluxes from marine macrophytes around the world, particularly in the Southern Hemisphere where net DOC fluxes from marine macrophytes are particularly scarce.

Despite the uncertainties described above, the global estimate of the net DOC release by marine macrophytes derived here provides a first-order approximation sufficient to assess whether macrophyte-derived DOC maybe a globally significant $\mathrm{C}$ flux in the ocean, thereby helping raise awareness on the importance of this process. The global net DOC export from these particular benthic ecosystems represents a small amount of the DOC pool in the ocean, however, it represents more than $50 \%$ of the annual global river input of DOC to the ocean that has been estimated to be $0.25 \mathrm{Pg} C$ (Cauwet, 2002). The global net DOC export from macrophyte communities represents a modest flux relative to the metabolism of the coastal ocean, but is significant relative to the net community production of benthic habitats and of a similar magnitude as organic carbon burial rates in coastal sediments (Duarte et al., 2005). The fate of the DOM exported from marine macrophyte communities is, however, unknown. DOM release represents an important, but poorly understood flux from macrophyte communities that may contribute to support metabolism in adjacent pelagic ecosystems. This potential carbon input to the open ocean might be altered due to anthropogenic pressures in the coastal ecosystem with different outcomes in the benthic ecosystems. Globally, seagrass area has declined by over 29\% (Waycott et al., 2009), however, macroalgae abundance has increase in coral reefs (Halpern et al., 2008) and some eutrophied environments. Consequently, net DOC fluxes from marine macrophytes in the coastal zone might increase in the near future due to the proliferation of macroalgae overcompensating for the decline in seagrass meadows if current human pressures in the coastal zone persists. 


\section{ACKNOWLEDGMENTS}

This work was funded by the European Commission projects EUROTROPH (contract EVK3-CT-2000-00040), PREDICT (contract IC18-CT98-0292), M\&M's (contract EVK3-CT2000-00044), the Spanish Plan of I+D (REN2001-4977-E) and IBIS project, co-financed by European Social Fund and the Greek Ministry of Development-GSRT. We thank R. Martínez, R. Santiago, and others who helped with field work, and R. Martínez and J. C. Alonso for nutrient analyses, D. Thomas for DOC analyses of SE Asian communities, D. A. Hansell and W. Chen for the DOC standards, and M. Fortes, T. Frazer, T. Bokn, and R. Santos for logistical assistance. We also thank P. Togeskov (Danisco Flexible, Denmark), for providing the plastic film used for the benthic chambers. Cristina Barrón was funded by a scholarship from the government of the Balearic Islands, a Juan de la Cierva fellowship from the Spanish Ministry of Economy and Competitivity and a research fellow scholarship from the Australian Research Council-discovery projects-120101778.

\section{REFERENCES}

Apostolaki, E. T., Holmer, M., Marba, N., and Karakassis, I. (2010a). Metabolic imbalance in coastal vegetated (Posidonia oceanica) and unvegetated benthic ecosystems. Ecosystems 13, 459-471. doi: 10.1007/s10021-010-9330-9

Apostolaki, E. T., Holmer, M., Marba, N., and Karakassis, I. (2010b). Degrading seagrass (Posidonia oceanica) ecosystems: a source of dissolved matter to the Mediterranean. Hydrobiologia 649, 13-23. doi: 10.1007/s10750-0100255-2

Barrón, C., and Duarte, C. M. (2009). Dissolved organic matter release in Posidonia oceanica meadow. Mar. Ecol. Prog. Ser. 374, 75-84. doi: 10.3354/meps07715

Barrón, C., Duarte, C. M., Frankignoulle, M., and Borges, A. V. (2006). Organic carbon metabolism and carbonate dynamics in a Mediterranean seagrass (Posidonia oceanica) meadow. Est. Coasts 29, 417-426. doi: 10.1007/BF02784990

Barrón, C., Marbà, N., Duarte, C. M., Pedersen, M. F., Lindblad, C., Kersting, K., et al. (2003). High organic carbon export precludes eutrophication effects in experimental rocky shore communities. Ecosystems 6, 144-153. doi: 10.1007/s10021-002-0402-3

Barrón, C., Marbà, N., Terrados, J., Kennedy, H., and Duarte, C. M. (2004). Community metabolism and carbon budget along a gradient of seagrass (Cymodocea nodosa) colonization. Limnol. Oceanogr. 49, 1642-1651. doi: 10.4319/lo.2004.49.5.1642

Benner, R., and Strom, M. (1993). A critical evaluation of the analytical blank associated with DOC measurements by high-temperature catalytic oxidation. Mar. Chem. 41, 153-160. doi: 10.1016/0304-4203(93)90113-3

Brilinsky, M. (1977). Release of dissolved organic matter by some marine macrophytes. Mar. Biol. 39, 213-220. doi: 10.1007/BF00390995

Calleja, M., Ll., Barrón, C., Hale, J., Notestein, S., Vaughan, D., Frazer, T., et al. (2006). Light regulation of benthic sulfate reduction rates mediated by seagrass (Thalassia testudinum) metabolism. Est. Coasts 29, 1255-1264. doi: 10.1007/BF02781825

Carritt, D. E., and Carpenter, J. H. (1966). Comparison and evaluation of currently employed modifications of the Winkler method for determining dissolved oxygen in seawater; a NASCO Report. J. Mar. Res. 24, 286-319.

Cauwet, G. (2002). "DOM in the coastal zone," in Biogeochemistry of Marine Dissolved Organic Matter, eds D. A. Hansell and C. A. Carlson (San Diego, CA: Academica Press), 579-609.

Charpy-Roubaud, C., and Sournia, A. (1990). The comparative estimation of phytoplanktonic and microphytobenthic production in the oceans. Mar. Microb. Food Webs 4, 31-57.

Chin-Leo, G., and Benner, R. (1991). Dynamics of bacterioplankton abundance and production in seagrass communities of a hypersaline lagoon. Mar. Ecol. Prog. Ser. 73, 219-230. doi: 10.3354/meps073219

del Giorgio, P. A., and Williams, P. J. B. (2005). "The global significance of respiration in aquatic ecosystems: from single cells to the biosphere," in Respiration in Aquatic Ecosystems, Chapter 14. (Oxford: Oxford University Press). doi: 10.1093/acprof:oso/9780198527084.003.0014
Duarte, C. M., and Cebrián, J. (1996). The fate of marine autotrophic production. Limnol. Oceanogr. 41, 1758-1766. doi: 10.4319/lo.1996.41.8.1758

Duarte, C. M., Marbà, N., Gacia, E., Fourqurean, J. W., Beggins, J., Barrón, C., et al. (2010). Seagrass community metabolism: assessing the carbon sink capacity of seagrass meadows. Glob. Biogeochem. Cycle 24, GB4032. doi: 10.1029/2010GB003793

Duarte, C. M., Martínez, R., and Barrón, C. (2002). Biomass, production and rhizome growth near the northern limit of seagrass (Zostera marina) distribution. Aquat. Bot. 72, 183-189. doi: 10.1016/S0304-3770(01)00225-X

Duarte, C. M., Middelburg, J. J., and Caraco, N. (2005). Major role of marine vegetation on the oceanic carbon cycle. Biogeosciences 2, 1-8. doi: 10.5194/bg2-1-2005

Gacia, E., Duarte, C. M., and Middelburg, J. J. (2002). Carbon and nutrient deposition in a Mediterranean seagrass (Posidonia oceanica) meadow. Limnol. Oceanogr. 47, 23-32. doi: 10.4319/lo.2002.47.1.0023

Gacia, E., Kennedy, H., Duarte, C. M., Terrados, J., Marbà, N., Papadimitriou, S., et al. (2005). Light-dependence of the metabolic balance of a highly productive Philippine seagrass community. J. Exp. Mar. Biol. Ecol. 316, 55-67. doi: 10.1016/j.jembe.2004.10.008

Gattuso, J.-P., Frankignoulle, M., and Wollast, R. (1998). Carbon and carbonate metabolism in coastal aquatic ecosystems. Annu. Rev. Ecol. Syst. 29, 405-434. doi: 10.1146/annurev.ecolsys.29.1.405

Gazeau, F., Duarte, C. M., Gattuso, J.-P., Barrón, C., Navarro, N., Ruiz, S., et al. (2005). Whole-system metabolism and CO2 fluxes in a Mediterranean Bay dominated by seagrass beds (Palma Bay, NW Mediterranean). Biogeosciences 2, 43-60. doi: 10.5194/bg-2-43-2005

Haas, A. F., Jantzen, C., Naumann, M. S., Iglesias-Prieto, R., and Wild, C. (2010). Organic matter release by the dominant primary producers in a Caribbean reef lagoon: implication for in situ $\mathrm{O}_{2}$ availability. Mar. Ecol. Prog. Ser. 409, 27-39. doi: 10.3354/meps08631

Halpern, B. S., Walbridge, S., Selkoe, K. A., Kappel, C. V., Micheli, F., D’Agrosa, C., et al. (2008). A global map of human impact on marine ecosystems. Science 319 , 948-952. doi: 10.1126/science.1149345

Hansell, D. A., and Carlson, C. A. (2002). Biogeochemistry of Marine Dissolved Organic Matter. San Diego, CA: Academica Press.

Hansell, D. A., Kadko, D., and Bates, N. R. (2004). Degradation of terrigenous dissolved organic carbon in the western Arctic ocean. Science 304, 858-861. doi: $10.1126 /$ science. 1096175

Hansen, H. P., and Koroleff, F. (1999). "Determination of nutrients," in Methods of Seawater Analysis, eds K. Grasshoff, K. Kremling, and M. Ehrhardt (Weinheim: Wiley-VCH), 170-193.

Hansen, J. W., Thamdrup, B., and Jørgensen, B. B. (2000). Anoxic incubation of sediment in gas-tight plastic bags: a method for biogeochemical process studies Mar. Ecol. Prog. Ser. 208, 273-282. doi: 10.3354/meps208273

Hemminga, M., and Duarte, C. M. (2000). Seagrass Ecology. Cambridge: Cambridge University Press.

Hendriks, I. E., Sintes, T., Bouma, T., and Duarte, C. M. (2008). Experimental assessment and modeling evaluation of the effects of seagrass ( $P$. oceanica) on flow and particle trapping. Mar. Ecol. Prog. Ser. 356, 163-173. doi: $10.3354 /$ meps07316

Holmer, M., Duarte, C. M., Boschker, H. T. S., and Barrón, C. (2004). Carbon cycling and bacterial carbon sources in pristine and impacted Mediterranean seagrass sediments. Aquat. Microb. Ecol. 36, 227-237. doi: 10.3354/ame036227

Hughes, A. D., Black, K. D., Campbell, I., Davidson, K., Kelly, M. S., and Stanley, M. S. (2012). Does seaweed offer a solution for bioenergy with biological carbon capture and storage? Greenhouse Gas Sci. Technol. 2, 402-407. doi: 10.1002/ghg

Kaldy, J. (2012). Influence of light, temperature and salinity on dissolved organic carbon exudation rates in Zostera marina L. Aquat. Biosyst. 8:19. doi: 10.1186/2046-9063-8-19

Kennedy, H., Beggins, J., Duarte, C. M., Fourqurean, J. W., Holmer, M., Marbà, N., et al. (2010). Seagrass sediments as a global carbon sink: isotopic constraints. Global Biogeochem. Cycles 24, GB4026. doi: 10.1029/2010GB003848

Kenworthy, W. J., and Thayer, G. W. (1984). Production and decomposition of the roots and rhizomes of seagrasses, Zostera marina and Thalassia testudinum, in temperate and subtropical marina ecosystems. Bull. Mar. Sci. 35, 364-379.

Khailov, K. M., and Burlakova, Z. P. (1969). Release of dissolved organic matter by marine seaweeds and distribution of their total organic production to inshore communities. Limnol. Oceanogr. 14, 521-532. 
Kirk, J. T. O. (1983). Light and Photosynthesis in Aquatic Ecosystems. Cambridge: Cambridge University Press.

Kritzberg, E. S., Arrieta, J. M., and Duarte, C. M. (2010). Temperature and phosphorus regulating carbon flux through bacteria in a coastal marine system. Aquat. Microb. Ecol. 58, 141-151. doi: 10.3354/ame01368

Llebot, C., Solé, J., Delgado, M., Fernández-Tejedor, M., Camp, J., and Estrada, M. (2011). Hydrographical forcing and phytoplankton variability in two semi- enclosed estuarine bays. J. Mar. Syst. 86, 69-86. doi: 10.1016/j.jmarsys.2011.01.004

Maher, D. T., and Eyre, B. D. (2010). Benthic fluxes of dissolved organic carbon in three temperate Australian estuaries: implications for global estimates of benthic DOC fluxes. J. Geophys. Res. 115, G04039. doi: 10.1029/2010JG0 01433

Maher, D. T., and Eyre, B. D. (2011). Insights into estuarine benthic dissolved organic carbon (DOC) dynamics using $\delta^{13} \mathrm{C}$-DOC values, phospholipid fatty acids and dissolved organic nutrient fluxes. Geochim. Cosmochim. Acta 75, 1889-1902. doi: 10.1016/j.gca.2011.01.007

Maie, N., Jaffé, R., Miyoshi, T., and Childers, D. L. (2006). Quantitative and qualitative aspects of dissolved organic carbon leached from senescent plants in an oligotrophic wetland. Biogeochemistry 78, 285-314. doi: 10.1007/s10533-0054329-6

Moriarty, D. J. W., Iverson, R. L., and Pollard, P. C. (1986). Exudation of organic carbon by the seagrass Halodule writhtii Aschers and its effect on bacterial growth in the sediment. J. Exp. Mar. Bio. Ecol. 96, 115-126. doi: 10.1016/00220981(86)90237-6

Mueller, B., van der Zande, R. M., van Leent, P. J. M., Meesters, E. H., Vermeij, M. J. A., and van Duyl, F. C. (2014). Effect of light availability on dissolved organic carbon release by Caribbean reef algae and corals. Bull. Mar. Sci. 90, 875-893. doi: 10.5343/bms.2013.1062

Pai, S.-C., Gong, G.-C., and Liu, K.-K. (1993). Determination of dissolved oxygen in seawater by direct spectrophotometry of total iodine. Mar. Chem. 41, 343-351. doi: 10.1016/0304-4203(93)90266-Q

Penhale, P. A., and Smith, W. O. (1977). Excretion of dissolved organic carbon by eelgrass (Zostera marina) and its epiphytes. Limnol. Oceanogr. 22, 400-407. doi: 10.4319/lo.1977.22.3.0400

Pregnall, A. M. (1983). Release of dissolved organic carbon from the estuarine intertidal macroalga Enteromorpha prolifera. Mar. Biol. 73, 37-42. doi: 10.1007/BF00396283

Roland, F., Caraco, N. F., Cole, J. J., and del Giorgio, P. (1999). Rapid and precise determination of dissolved oxygen by spectrophotometry: evaluation of interference from color and turbidity. Limnol. Oceanogr. 44, 1148-1154. doi: 10.4319/lo.1999.44.4.1148

Santos, R., Silva, J., Alexandre, A., Navarro, N., Barrón, C., and Duarte, C. M. (2004). Ecosystem metabolism and carbon fluxes of a tidal-dominated coastal lagoon. Estuaries 27, 977-985. doi: 10.1007/BF02803424
Suzuki, Y., Fujii, M., Casareto, B. E., Furuta, A., and Ishikawa, Y. (2003). $\mathrm{CO}_{2}$ sequestration and fate of organic matter with seagrass (Zostera marina) ecosystems. J. Chem. Eng. Jpn. 36, 417-427. doi: 10.1252/jcej.36.417

Vaquer-Sunyer, R., Duarte, C. M., Jorda, G., and Ruiz-Halpern, S. (2012). Temperature dependence of oxygen dynamics and community Metabolism in a shallow Mediterranean macroalgal Meadow (Caulerpa prolifera). Est. Coasts 35, 1182-1192. doi: 10.1007/s12237-012-9514-y

Velimirov, B. (1986). DOC dynamics in a Mediterranean seagrass system. Mar. Ecol. Prog. Ser. 28, 21-41. doi: 10.3354/meps028021

Vonk, J. A., Middelburg, J. J., Stapel, J., and Bouma, T. J. (2008). Dissolved organic nitrogen uptake by seagrasses. Limnol. Oceanogr. 53, 542-548. doi: 10.4319/lo.2008.53.2.0542

Wada, S., and Hama, T. (2013). The contribution of macroalgae to the coastal dissolved organic matter pool. Est. Coast. Shelf Sci. 129, 77-85. doi: 10.1016/j.ecss.2013.06.007

Waycott, M., Duarte, C. M., Carruthers, T. J. B., Orth, R. J., Dennison, W. C., Olyarnik, S., et al. (2009). Accelerating loss of seagrasses across the globe threatens coastal ecosystems. Proc. Natl. Acad. Sci. U.S.A. 106, 12377-12381. doi: 10.1073/pnas.0905620106

Wetzel, R. G., and Penhale, P. A. (1979). Transport of carbon and excretion of dissolved organic carbon by leaves and roots/rhizomes in seagrasses and their epiphytes. Aquat. Bot. 6, 149-158. doi: 10.1016/0304-3770(79)90058-5

Ziegler, S., and Benner, R. (1999). Dissolved organic carbon cycling in a subtropical seagrass-dominated lagoon. Mar. Ecol. Prog. Ser. 180, 149-160.

Ziegler, S., Kaiser, E., and Benner, R. (2004). Dynamics of dissolved organic carbon, nitrogen and phosphorus in a seagrass meadow of Laguna Madre. Texas. Bull. Mar. Sci. 75, 391-407.

Conflict of Interest Statement: The authors declare that the research was conducted in the absence of any commercial or financial relationships that could be construed as a potential conflict of interest.

Received: 18 July 2014; paper pending published: 12 August 2014; accepted: 04 September 2014; published online: 06 October 2014.

Citation: Barrón C, Apostolaki ET and Duarte CM (2014) Dissolved organic carbon fluxes by seagrass meadows and macroalgal beds. Front. Mar. Sci. 1:42. doi: 10.3389/ fmars.2014.00042

This article was submitted to Marine Biogeochemistry, a section of the journal Frontiers in Marine Science.

Copyright (๑) 2014 Barrón, Apostolaki and Duarte. This is an open-access article distributed under the terms of the Creative Commons Attribution License (CC BY). The use, distribution or reproduction in other forums is permitted, provided the original author(s) or licensor are credited and that the original publication in this journal is cited, in accordance with accepted academic practice. No use, distribution or reproduction is permitted which does not comply with these terms. 